\title{
What's Driving the New Economy?: The Benefits of Workplace Innovation
}

\author{
by \\ Sandra E. Black \\ and \\ Lisa M. Lynch \\ Final Revision \\ October 2003
}

This research was supported in part by the National Science Foundation Program on Innovation and Organizational Change under Grant number 9975878. The authors would like to thank Anya Krivelyova for excellent research assistance. This paper has benefitted from comments by Fabio Schiantarelli, Dan Sichel, Kevin Stiroh, and participants in seminars at Princeton University, Harvard University, MIT, the NBER, the Institute of Fiscal Studies, the Board of Governors of the Federal Reserve Bank, and three anonymous referees. The research in this paper was conducted while the authors were Census Bureau Research Associates at the Boston Research Data Center. Research results and conclusions expressed are those of the authors and do not necessarily indicate concurrence by the Bureau of the Census, the National Science Foundation, or the National Bureau of Economic Research, the Federal Reserve Bank of New York or the Federal Reserve System. This paper has been screened to ensure that no confidential data are revealed.

(C)2003 by Sandra E. Black and Lisa M. Lynch. All Rights reserved. Short sections of text, not to exceed two paragraphs, may be quoted without explicit permission provided that full credit, including (C) notice, is given to the source. 
Pagehead Title: What's Driving the New Economy?

\begin{abstract}
$\underline{\text { ABSTRACT }}$
This paper argues that changes in workplace organization, including the usage of selfmanaged teams, incentive pay, and employee voice, have been a significant component of the turnaround in productivity growth in the United States during the 1990s. Our work goes beyond measuring the impact of computers on productivity and finds that these types of workplace innovation appear to explain a large part of the movement in multi-factor productivity in the United States over the period 1993-1996. These results suggest additional dimensions to the recent productivity growth in the US that may well have implications for productivity growth potential in Europe.
\end{abstract}

Sandra E. Black

Department of Economics

UCLA, NBER, and IZA

Box 951477

Los Angeles, CA 90095-147733

Email: sblack@econ.ucla.edu
Lisa M. Lynch

Fletcher School of Law \& Diplomacy

Tufts University, NBER and IZA

160 Packard Ave.

Medford, MA 02155

Email: lisa.lynch@tufts.edu 
In spite of recent accounting scandals in the United States that have cast suspicion on the actual financial performance of an increasing number of firms, the productivity numbers still suggest that during the latter half of the 1990 s through the $1^{\text {st }}$ quarter of 2003 something "new" is occurring in the U.S. economy. From 1960 until the 1973 oil shock, average annual productivity growth, as measured by output per hour, grew approximately 3 percent per year for U.S. nonfinancial corporations. This growth rate then declined to around 1.7 percent per year from 1973-1995. However, since 1995, average annual labor productivity growth for nonfinancial corporations has risen back up to around 3 percent. Additionally, U.S. manufacturing productivity grew even faster at almost 4.4 percent annually during the second half of the 1990s. One consequence of this turnaround in productivity in the United States, as detailed in Scarpetta et. al. (2000), is that the convergence towards the U.S. standard that we observed in manufacturing productivity across industrialized countries from 1960-1980 has stopped or even reversed for countries such as the United Kingdom, Canada, and Germany.

This resurgence of productivity growth has led many to argue that a "New Economy" has been created in the United States. This "New Economy" is characterized in part by firms increasing their capital investments, especially in information-technology software and hardware. In addition, as we will present in this paper, more firms have adopted work processes in which an increasing proportion of non-managerial workers are involved in problem solving and identifying opportunities for innovation and growth. Increased managerial focus on quality management, continuous innovation, incentive based compensation, and employee involvement programs has in turn raised the productive capacity of the U.S. economy.

Until recently, there has been limited causal evidence on the role of technology and 
workplace innovation in generating rising productivity in the U.S. during the 1990s. There has also been significant controversy over the extent to which investments in information technology actually contributed to the so called productivity miracle in the US in the 1990s. For example, Gordon (2003) argues that the role of computers for the late 1990s boom is the US was greatly exaggerated. However, Oliner and Sichel (2002) conclude that in spite of the financial collapse of the high tech sector, the link between IT and productivity remains. They present evidence that the acceleration in labor productivity in the U.S. during second half of the 1990s was driven by both the greater use of IT goods and efficiency gains in the production of IT goods.

In spite of this debate about the relative importance of IT, there does seem to be some agreement that IT does not explain the entire U.S. productivity story. Gordon (2003) argues that early estimates of the contribution of IT investment on productivity were biased upwards for a variety of reasons that included unrealistic assumptions about the speed at which computers affect productivity, micro level evidence that productivity growth in the U.S. retail sector has been driven by other factors, and a comparative analysis of the retail sector in the U.S. and Europe where businesses use the same information technology but still having large differences in productivity growth. Studies by Oliner and Sichel (2000) and Jorgenson and Stiroh (2000) have attempted to decompose labor productivity growth into contributions coming from capital deepening and multifactor productivity growth (the growth in output that can not be accounted for by changes in labor and capital inputs). They find that slightly more than fifty percent of the growth in output in the U.S. during the 1990s in private nonfarm businesses can be explained by multifactor productivity growth. As shown in Fig. 1, when one looks only at the manufacturing sector, multifactor productivity growth was an extremely important component of output growth 
during the 1990s. Therefore, getting a better understanding of what factors might be driving multifactor productivity growth would be an important step forward in understanding what is driving the "New Economy". In addition, the nature of these factors will influence the degree of optimism one may have about the long run sustainability of the New Economy in the United States and the ability of other countries to replicate such productivity growth.

We use a unique sample of U.S. businesses over the period 1993-1996 to examine the role of information technologies (computers) and other capital investment, workplace innovation (including team-work, employee involvement in decision-making and re-engineering activities, and profit sharing), and worker characteristics (education, turnover, gender and race) on productivity. We match plant level practices with plant level productivity and estimate production functions using both cross sectional and longitudinal data. The existence of panel data allows us to control for unobserved time invariant establishment characteristics although it does not control for time-varying unobserved heterogeneity. Ideally we would have preferred to examine a longer time period; however, one advantage of examining this specific period of time is that it covers the turning or inflection point in labor productivity observed in the aggregate U.S. data.

Consistent with our earlier work (Black and Lynch 1996 and 2001), we find that high performance practices are related to firm productivity. Specifically, we find a positive and significant relationship between the proportion of non-managers using computers and the productivity of establishments. We find that firms that re-engineer their workplaces to incorporate more high performance practices experience higher productivity. Profit sharing is also associated with higher productivity. In addition, we find that employee voice (proxied by 
the percentage of workers who regularly meet to discuss workplace issues) has a larger positive effect on productivity when it is done in the context of unionized establishments. These results suggest that changes in workplace organization may explain a significant portion of trends in U.S. productivity growth that have been attributed to the New Economy.

\section{Background Discussion}

Before we discuss how changes in workplace practices are associated with changes in labor productivity, we must first detail our proxies for workplace innovation. As with other intangible assets, there is no consensus definition of what are the best measures of workplace innovation. ${ }^{1}$ However, as shown in Fig. 2, we see that many employers, interviewed in a 1996 nationally representative sample of U.S. establishments, use a variety of workplace practices that have been often labeled "high performance workplace practices". Consistent with aggregate data on business investment in information technology, we see that over forty percent of U.S. employers reported that three quarters or more of their production workers or frontline employees used computers in their job. However, there is considerable workplace innovation beyond the use of computers by non-managerial workers. For example, in 1996 almost half of all U.S. employers reported that three quarters or more of their employees were involved in regular meetings to discuss workplace issues. In addition, over forty percent of employers had some form of profit sharing or stock option plan for employees and seventeen percent of employers reported that a quarter or more of their employees worked in self-managed teams. During the 1990s, many employers revamped their organizational design; we find that more than

${ }^{1}$ For a more detailed discussion, see Black and Lynch (2003). 
a quarter reported that they undertook significant re-engineering efforts over the period 19931996. Finally, the majority of employers reported that the skills required to perform production or support jobs at an acceptable level had increased over the period 1993-1996. Only six percent reported that skill levels had fallen.

While there was a great deal of organizational change that occurred during the period 1993-1996, the direction of the changes in organizational practices was not the same for all employers. For example, as shown in Table 1, while thirty percent of employers changed their usage of profit sharing for employees over the period of 1993-1996, much of that was away from profit sharing. The extent of employers' usage of extensive employee consulting on workplace issues also changed in both directions over this time period. So there is considerable variation in the usage of various workplace practices by U.S. employers and this usage changes over time during the 1990s.

Freeman and Lazear (1995) provide a theoretical framework for understanding the linkage between workplace practices and productivity. While their work focuses on the role of works council it can easily be extended to high performance workplace practices. In their model, firms can increase total rents by giving employees a voice in management and production decisions. However, they do so at a cost; the more voice they give to employees, the greater the share of rents the employees will appropriate. Their model shows that there is some socially optimal amount of voice/rent taking and that those firms who maximize their own share of the rents and not total rents will under-provide "voice" to workers. A final implication of their model is that we would expect to see a positive association between workplace innovation and productivity. 
There is also a growing theoretical and empirical debate on the existence of synergies in bundles of human resource practices. Milgrom and Roberts (1995) argue that the impact of a system of human resource practices will be greater than the sum of its parts because of the synergistic effects of bundling practices together. Kandel and Lazear (1992) show that introducing a profit-sharing plan for all workers in a firm may have little or no impact on productivity unless it is linked with other practices that address the inherent free rider problem associated with corporate wide profit sharing plans. Ichniowski et. al. (1997) present compelling empirical evidence in the US steel industry that systems of practices are more important for productivity than individual practices.

The empirical work presented in this paper is not the first to examine the impact of workplace practices on the productivity of businesses, but there have been limitations with this earlier work. ${ }^{2}$ Some of the most detailed and insightful work on the adoption and nature of new workplace practices has been done on a case study basis. ${ }^{3}$ Although these studies have provided us with a wealth of information on the chain of events that resulted in the adoption of new workplace practices, it is difficult to generalize these results to a broader spectrum of the economy.

One solution to this problem is to conduct a detailed intra-industry study of the adoption of workplace practices such as was done for the steel industry by Ichniowski, Shaw and Prennushi (1997). The advantage of intra-industry studies is that one can collect a high degree

${ }^{2}$ See Black and Lynch (2001) for a more detailed review of the literature.

${ }^{3}$ This includes for example work on auto plants by Krafcik (1988) and Womack, Jones and Roos (1991), apparel plants by Berg, Appelbaum, Bailey, and Kalleberg (1995), and a regional phone company by Batt (1995). 
of detailed information on the variation of practices within a sector and see how they are related to variations in performance. ${ }^{4}$ By examining human resource practices associated with one specific production process it is possible to greatly reduce problems of underlying heterogeneity of production processes. Most of the intra-industry studies conclude that the adoption of a coherent system of new human resource management practices such as flexible job definitions, cross-training, and work teams, along with extensive reliance on incentive pay, results in substantially higher levels of productivity than more traditional human resource management practices (less flexible, close supervision, and hourly pay). While these results represent an important contribution to the literature on workplace practices and productivity, it is again not easy to generalize these findings for a broader segment of the economy.

Another research strategy, which is applied here, is to survey a more representative sample of firms (typically a cross section but also longitudinal) and examine the relationship between workplace practices and broader measures of performance such as productivity or profitability. Though one has less detailed information on specific practices than in the case studies or intra-industry studies, the results are generalizable to a much broader group of establishments. A number of papers have examined this relationship and found a significant correlation between human resource management systems and various measures of business performance, including work on US employers by Ichniowski (1990), Huselid (1995), Huselid and Becker (1996), Italian employers by Cristini, Gaj, Labory, and Leoni (2001), French employers by Caroli and Van Reenen (2001), and Japanese employers by Kato and Morishima

${ }^{4}$ Other examples of intra-industry studies include work by Kelley (1994 and 1996) on the machine tool industry, and Bailey (1993) and Dunlop and Weil (1996) on the apparel industry. 
(2002). But much of this work has been plagued by problems such as low survey response rates and the use of indexes of workplace practices, which lead to ambiguities in interpretation.

In earlier work (Black and Lynch 1996 and 2001) we examined the impact of workplace innovation on labor productivity using cross sectional data from a representative sample of U.S. manufacturing employers in 1993. This survey contained a wealth of information on workplace organization, information technology, and human capital investments of individual employers during 1993. We used these data along with additional longitudinal information on past output, employment and capital investment to estimate the relationship between workplace practices and labor productivity. In both of these studies, we found that workplace practices do matter for labor productivity. However, we found that what was associated with higher productivity was not so much whether an employer adopted a particular work practice but rather how that work practice was actually implemented within the establishment. For example, simply adopting a Total Quality Management system has an insignificant or negative impact on productivity unless the proportion of workers involved in regular decision making within the plant is also high. In other words, it is not so much what you say you do, but how you do it that matters.

We also found important differences across plants on the basis of the type of labormanagement relations within the plant. Establishments with more traditional unionized labormanagement relations including little or no direct participation of employees in decision making had substantially lower productivity than unionized plants that had adopted new workplace practices such as incentive-based compensation and greater employee participation in decision making. In addition, these unionized plants performed much better than even non-union plants 
that had adopted similar high performance workplace practices. ${ }^{5}$

These findings suggest that establishment practices that encourage workers to think and interact in order to improve the production process are strongly associated with increased firm productivity. We found that the higher the average educational level of production workers within a plant is, the more likely the plant has performed better than average over the period 1988-1993. In addition, although the proportion of managerial workers who use computers had no impact on labor productivity, the greater the proportion of non-managerial workers who use computers, the higher was plant productivity. ${ }^{6}$

While there are strengths and weaknesses associated with all of the above-mentioned empirical research, the primary advantage of the work presented in this paper is that we are able

${ }^{5}$ Workers may be more willing to participate in employee involvement programs if they feel the union will protect their employment security. Agreements made between managers and workers may not be legally enforceable so the presence of unions, as discussed by Malcomson (1983), can address incentive compatibility problems that may arise at the workplace. In addition, negotiations that management undertakes with workers about the introduction of new workplace practices are less expensive if the company only has to deal with union specialists rather than each individual worker.

${ }^{6}$ In work that builds on our earlier research, Cappelli and Neumark (2001), using the same surveys in this paper, examined the relationship between productivity, wages, and workplace practices. However, they only studied manufacturing establishments in who were in existence from 1977-1996. They estimated the impact of workplace practices on the change in labor productivity of these establishments over the period 1977-1993 and 1977-1996. Howevert, any manufacturing establishment that was "born" after 1977 is excluded from their analysis. They do this to address the problem of omitted variable bias associated with unobserved establishment characteristics, but the assumption that no U.S. establishments in 1977 used any high performance practices (e.g., profit sharing, employee participation in decision making, or investments in human capital) is an incorrect characterization of U.S. employers. In addition, many firms during the 1980s and 1990s opened brand new plants to implement new forms of workplace organization. To exclude these types of establishments as well from the analysis significantly reduces the generalizability of the results and may bias them against finding any effect of workplace practices on productivity. 
to exploit a rich panel data set from a nationally representative survey of establishments to determine whether the effects of workplace innovation obtained at the firm-specific or industryspecific level hold more generally. Having observations on establishments at two different points in time is crucial because it allows us to control for all unobserved time invariant establishment characteristics. The length of time between the two surveys is long enough for a significant number of changes in workplace practices to have occurred and short enough to minimize the problem of "births" and "deaths" of establishments that could limit the generalizability of our results. The survey (both the cross sections and the panel component) has a higher response rate than most previous studies, and it contains very detailed information on specific employer practices. We test for the importance of synergies in human resource management practices, match plant level practices with plant level outcomes, and analyze the effects of these practices on objective measures of productivity by estimating production functions on both cross sectional and longitudinal data.

We are also able to examine the relationship between computers and productivity. Recent work by Oliner and Sichel (2000) and Jorgenson and Stiroh (2001) find that a great deal of the productivity growth in the second half of the 1990s can be explained by information technology. ${ }^{7}$ But computers may have more than just a direct effect on productivity of firms. As discussed in Bresnahan, Brynjolfsson, and Hitt (2002), information technologies can also have

\footnotetext{
${ }^{7}$ In addition, researchers such as Brynjolfsson and Hitt (2002) who use micro-based data found a positive relationship between computers and productivity while Krueger (1993) found that workers who worked with computers were paid approximately 15 percent more than similar workers who did not work with computers. Doms, Dunne and Troske (1997), using plant-level data on businesses in SIC 34-38 that was matched with micro data on a sample of individuals within each of their establishments, found a positive relationship between computers and other advanced technologies on the one hand and pay and labor productivity on the other hand.
} 
an important effect on the ability of firms to implement organizational changes such as reorganizing production and giving workers more power in decision making - the so-called spillover effect from investing in information technology. In one of the few empirical studies of investments in information technologies and organizational change, Bresnahan, Brynjolfsson, and Hitt (2002) find evidence for complementarities between technology, organizational changes and skills. Unfortunately their work uses just cross sectional micro data on workplace practices. We will be able to examine both computer use and other workplace innovations to see their respective impact on productivity.

Given the detailed time varying information contained in this panel data on workplace practices and technology, we can reduce the classic simultaneity problem that has been highlighted in the context of estimating production functions by a variety of authors, including recently Levinsohn and Petrin (2000), by estimating a fixed effects model. However, even though we have much more information on plant characteristics than is typically available in micro studies of production functions, we may still have a problem with biased parameter estimates if there remains any significant unobserved time varying differences across plants. In addition, the workplace practices themselves may well be endogenous. For example, those establishments that become more productive (and in turn more profitable) for reasons other than changes in workplace practices may decide that they can now afford to introduce new workplace practices. We considered using instrumental variables to address this endogeneity problem but it is extremely difficult, especially at the plant level, to find valid instruments that are both correlated with the choice of workplace organization and orthogonal to such productivity shocks. However, by incorporating the detailed time varying information on plant level characteristics 
available to us, along with examining a relatively short period of time, we hope to reduce both the simultaneity and endogeneity problems relative to previous studies.

\section{The Data}

In order to understand the nature and importance of our contribution, it is useful to start with a description of the data set used in the empirical estimation. The first round of the Educational Quality of the Workforce (EQW) National Employers Survey was administered by the U.S. Bureau of the Census as a telephone survey in August and September 1994 to a nationally representative sample of more than 3,000 private establishments with more than 20 employees. The survey represents a unique source of information on how employers recruit workers, organize work, invest in physical capital, and utilize education and training investments. The survey over-sampled establishments in the manufacturing sector and establishments with more than 100 employees. Public sector employees, not-for-profit institutions, and corporate headquarters were excluded from the sample. The target respondent in the manufacturing sector was the plant manager and in the non-manufacturing sector was the local business site manager. However, the survey was designed to allow for multiple respondents so that information could be obtained from establishments that kept financial information such as the book value of capital or the cost of goods and materials used in production at a separate finance office (typically at corporate headquarters for multiestablishment enterprises). The sample frame for the survey was the Bureau of the Census Standard Statistical Establishment Listing file, one of the most comprehensive and up-to-date listings of establishments in the United States. Although the sampling frame omits 
establishments with less than 20 employees, it captures establishments that employ approximately three-quarters of all workers in the United States.

The response rate in the first round EQW National Employers Survey for manufacturing establishments was 75 percent. This is substantially higher than most other voluntary establishment surveys. Of the 1,831 manufacturing establishments who participated in the survey, not all respondents completed all parts of the survey by the interview cutoff date of October 1, 1994. Therefore, the final number of manufacturing establishments in the sample for which all parts of the survey were completed was 1,621 . This represents a 66 percent 'completed' survey response rate.

A second survey was administered by the Census Bureau in August 1997. ${ }^{8}$ There was oversampling of establishments in California, Kentucky, Michigan, Maryland and Pennsylvania and a subsample of establishments that had been contacted in the first round. The final sample of completed interviews for the second round of the EQW-NES included 2,479 manufacturing establishments, representing a 63 percent response rate. A panel of 766 establishments (both manufacturing and non-manufacturing) can be constructed between the two rounds of the EQWNES. The panel response rate (for first round establishments who were contacted and completed the interview in the second round) was 74 percent. The second survey was considerably longer in duration than the first survey (close to 45 minutes). Therefore, in spite of the high overall response rate there is a high percentage of businesses that do not provide information on all questions asked including items such as the value of shipments and sales, the book value of the

${ }^{8}$ For more detailed information on response rates for the EQW-NES II see the following internet address: http://www.irhe.upenn.edu/cgi-bin/cat.pl\#nes1997. 
capital stock, and the costs of materials. This will reduce the final sample sizes used for analysis in this paper.

\section{Empirical Results}

As a starting point, we first used the second wave of the survey (EQW-NES II) and estimated cross-section production functions to examine whether the estimated impact of workplace practices, technology and worker characteristics on labor productivity in 1996 are similar to those found using the 1993 data (see Black and Lynch 1996, 2001). These equations are of the form:

$$
\ln (\mathrm{Y} / \mathrm{L})_{\mathrm{i}}=\alpha \ln (\mathrm{K} / \mathrm{L})_{\mathrm{i}}+\beta \ln (\mathrm{M} / \mathrm{L})_{\mathrm{i}}+\delta \mathrm{Z}_{\mathrm{i}}+\epsilon_{\mathrm{i}}
$$

and

$$
\ln (\mathrm{Y} / \mathrm{P})_{\mathrm{i}}=\alpha \ln (\mathrm{K} / \mathrm{P})_{\mathrm{i}}+\beta \ln (\mathrm{M} / \mathrm{P})_{\mathrm{i}}+\gamma \ln (\mathrm{N} / \mathrm{P})_{\mathrm{i}}+\delta^{\prime} \mathrm{Z}_{\mathrm{i}}+\epsilon_{\mathrm{i}}
$$

where $\mathrm{Y}$ is the real total value of shipment and sales, $\mathrm{K}$ is the real book value of the capital stock, $M$ is the real cost of materials, $\epsilon_{\mathrm{i}}$ is an error term and $\delta^{\prime}$ is a vector of coefficients on $Z_{\mathrm{i}}$ which are establishment specific workplace practices and characteristics of employees such as education and turnover. In equation (1) L is the sum of all workers in the establishment and in equation (2) we differentiate between the total number of production workers $(\mathrm{P})$ and nonproduction workers $(\mathrm{N}){ }^{9}$

We augment the standard Cobb Douglas production function by allowing productivity to depend upon workplace practices, plant specific human capital measures, the diffusion of

${ }^{9}$ Note that we are constraining the model here to assume constant returns to scale but we will test this assumption in our empirical work. 
information technology, employee turnover rates, age distribution of the capital stock, and other characteristics of the establishments using data from the EQW-NES II. Since we are trying to understand the tremendous growth in manufacturing productivity during the 1990 s, we only focus only on manufacturing firms in this paper. Total sales, capital, and material numbers for manufacturing establishments in our survey are adjusted using deflators from the NBER Productivity Database assembled by Eric Bartelsman and Wayne Gray (1996) and updated recently with the support of Randy Becker at the Census Bureau. (See the Data Appendix for more details)..$^{10}$

One problem with the EQW-NES is that while there is a very high overall response rate, questions such as the total value of shipments or sales or the book value of the capital stock had high non-response rates. However, by design, many of the manufacturing establishments in the EQW survey could be matched with the Census Bureau's Longitudinal Research Database, (LRD). In this way we are able to replace missing data from the EQW survey with data from the LRD. This allows us in the cross section analysis to nearly double our sample size from 760 to 1493 observations ${ }^{11}$.

${ }^{10}$ Although we deflate total sales by detailed industry price deflators this does not control for product quality differences that may exist at the plant level. As detailed in Melitz (2000) this can result in an additional source of bias. Those plants that produce higher quality goods will appear to be more productive when industry level deflators are used. If those businesses with higher quality goods or more diversified production also use different types of work organization what we attribute to workplace practices may in fact just reflect unobserved differences in products.

${ }^{11}$ We were concerned about how correlated LRD data on sales and employees would be with EQW data. Therefore we compared values on sales, capital, material costs, and employment from the LRD and EQW. We had to construct a book value of the capital stock for the LRD which we did following Black and Lynch 2001. We found the following correlation coefficients - for sales 0.91 , for capital 0.79 , for material costs 0.67 and for employment 0.96 . 
Table 2 presents the results when we use the 1996 survey and estimate cross section production functions (equations 1 and 2 above). The results presented in this table are largely consistent with our earlier work. We find estimated coefficients on capital, labor, and materials that are reasonable and similar to those in our previous work. This carries through when we divide labor into production and non-production workers and use sales/production workers as our dependent variable (Columns 2 and 3$).{ }^{12}$

Also consistent with our earlier work, we find a positive and significant relationship between the proportion of non-managers using computers, suggesting that the diffusion of information technology is associated with higher productivity. In addition, having a greater proportion of total capital stock 1-4 years old is positively associated with productivity. Note that the share of the capital stock less than one year old is insignificant which may indicate a "learning curve" associated with the introduction of new technology. In results not reported here we find that the proportion of managers using computers does not have a significant impact on establishment labor productivity.

We find that some worker characteristics are related to productivity. For example, the overall educational level of the establishment (constructed by using the average education of each of five occupational categories and then using employment shares as weights) is positively related to labor productivity but when we divide labor into production and non-production workers in equations 2 and 3 , education of non-production workers is not statistically significant.

We always include a dummy variable in our estimation to indicate if the data on sales, capital, materials are obtained from the LRD or not and this is never significant.

${ }^{12}$ The imposition of constant returns to scale is always accepted. Note that standard errors are adjusted for heteroskedasticity. 
However, the average education of production workers is significant but negatively related to labor productivity. This may be due to the fact that we are not able to control for average experience or tenure in our equations. Higher turnover, as proxied by the proportion of the workforce with tenure less than one year, does appear to significantly reduce productivity as it did in our earlier work using 1993 data. Finally, the proportion of workers who are women or minorities has no impact on labor productivity.

When we turn to workplace innovations we find that high performance workplace practices and employee voice appear to be significantly related to establishment productivity. Incentive schemes do matter, as establishments that offer profit sharing or stock options to any employees as a part of the compensation package have higher productivity. Re-engineering ${ }^{13}$ is significant in some of the specifications but bench-marking appears to have little impact on labor productivity. In terms of the impact of employee voice on labor productivity, we find that unionized businesses have higher productivity. However, increasing the proportion of workers that meet on a regular basis has a negative effect on productivity, although this is usually insignificant. When we examine the interaction of workplace practices in equation 3 of Table 1 we find that unionized establishments with profit sharing have lower labor productivity while unionized establishments that underwent a re-engineering effort have higher labor productivity.

\footnotetext{
${ }^{13}$ Re-engineering is the answer to the survey question "has the establishment has engaged in a major reorganization at any time over the past three years?". Therefore, this variable is more appropriately considered as a change variable that we would expect to have a more significant impact in the fixed effect estimation. Management consultants typically define reengineering as moving away from organizing work on the basis of functional silos and relying instead on cross-functional operations and communications. Re-engineering efforts are not necessarily independent of technological change but are focused on the organization of work. When we drop the re-engineering variable from the cross section estimation none of the other reported coefficients changes.
} 
While the profit sharing result is a bit perplexing, the unionization interaction with reengineering is consistent with the idea that unions provide the necessary job security to make workplace reorganization effective.

In an effort to try to distinguish whether or not there are synergies between information technology and workplace structure, we tried interacting the percentage of nonmanagerial workers using computers with various measures of workplace organization such as the percentage of workers meeting in groups, profit sharing, the number of managerial levels in the establishment, and whether or not the firm has undergone reengineering in the last three years. None, however, were statistically significant. We also tried interacting profit sharing with workplace practices to attempt to determine whether these workplace practices are more effective in the presence of incentive schemes as suggested in Boning, Ichniowski, and Shaw 2001. Again, however, none of these interactions were statistically significant.

In spite of the fact that we are able to control for many more managerial practices than most previous studies on productivity, our cross section estimates may still be subject to omitted variable bias (see Griliches and Mairesse 1995) due to unobserved establishment characteristics. ${ }^{14}$ With two waves of survey data, we are able to begin to address some of these

\footnotetext{
${ }^{14} \mathrm{An}$ example of an omitted variable that may be correlated with our workplace practices and consequently generate biases is managerial quality. It may be the case that the presence of good managers is more likely to be observed in firms with high performance workplace practices. Therefore, what looks like an effect of workplace practices on productivity is just good management. If it is true that good managers are those who adopt incentive-based compensation, get a higher proportion of their workers involved in decision making, and train a higher proportion of workers to use computers, then the fact that we are able to include these variables explicitly as regressors in our analysis means that there may not be much unobserved managerial quality left. However, the coefficients on workplace practices will capture the combined effects of the practice itself and the quality of management. These two effects should be accounted for separately.
} 
concerns. Consider the following equation:

$$
\mathrm{Y}_{\mathrm{it}}=\alpha^{\prime} \mathrm{X}_{\mathrm{it}}+\delta^{\prime} \mathrm{Z}_{\mathrm{it}}+v_{\mathrm{i}}+\epsilon_{\mathrm{it}}
$$

where $\mathrm{Y}$ is sales per production worker; $\alpha^{\prime}$ is a vector of coefficients on capital per production worker, materials per production worker, and the number of nonproduction workers per production worker; $\delta$ ' is our vector of coefficients on workplace practices from the EQW-NES survey; $v_{\mathrm{i}}$ is an unobserved time invariant establishment fixed effect; and $\epsilon_{\mathrm{it}}$ is the idiosyncratic component of the error term. Since we have two years worth of data, if we take deviations from an establishment's mean or, equivalently, take first differences of equation (3), all firm observed and unobserved time invariant fixed effects drop out and we can remove the bias in estimating the coefficients in vectors $\alpha^{\prime}$ and $\delta^{\prime}$ that occurs because of the omission of the establishment fixed effect. We are thereby able to exploit the panel nature of our data set and obtain estimates based on changes in workplace practices and how they are related to changes in establishment productivity. As discussed earlier, there will still remain possible biases due to unobserved time varying characteristics of the establishment. Unfortunately, it is not possible to determine the direction of the biases on the estimated coefficient if there is simultaneity bias and there are many inputs that may be correlated with the error. However, in the fixed effects model, if there is measurement error this will likely generate a downward bias on the estimated coefficients for workplace practices.

Table 3 presents the results when we use our two waves of the EQW-NES survey to estimate equation 3 allowing for establishment fixed effects. The dependent variable is the difference in labor productivity across the two surveys and all of the explanatory variables are in first differences. The sample size is smaller (284 establishments) because we are restricted to 
using only those establishments that completed the survey in both years and had data on all variables in each survey year. The findings are broadly consistent with those presented in Table 2 , which is perhaps surprising given that our results on the effect of workplace innovations are identified using their changes over a three-year period. If there are few changers over this period it may be difficult to find any significant effect. However, as shown in Table 1, there is considerable movement in workplace practices over this three year period of time and these changes are not all in the same direction.

Our estimated coefficients on capital and materials are consistent with previous research and are all statistically significant with the expected sign. In addition, we again find that information technology matters, as the proportion of non-managers using computer is positively related to labor productivity and statistically significant. In terms of the impact of worker characteristics on productivity, we find little effect of education on productivity, but this is likely due to the fact that the average educational level was virtually unchanged over this period. As in the cross section results, we find that higher worker turnover has a negative impact on labor productivity.

Again, workplace practices do matter. We find that firms that re-engineer their workplaces experience higher labor productivity even after controlling for time invariant fixed effects, but now we find no impact of profit sharing and/or stock options on labor productivity. In addition, we find after controlling for fixed effects that increased use of self-managed teams is associated with lower labor productivity. ${ }^{15} \quad$ Finally, when we examine interaction effects we

\footnotetext{
${ }^{15}$ This could be due to the fact that some workplace practices, when adopted, take a while to improve productivity. Consistent with this idea is the negative (although not statistically significant) coefficient on the interaction re-engineering and the percentage meeting to discuss
} 
find that unionized establishments with a higher proportion of workers meeting regularly in groups to discuss workplace issues are also more productive. In other words, the best performing establishments are those who are both unionized and have adopted greater employee participation in decision making.

At the start of this paper we discussed how important multifactor productivity has been during the 1990s in the United States in terms of driving output growth, especially in the manufacturing sector. We can use our estimates of the impact of workplace practices on labor productivity in a growth accounting framework and see how much of overall growth in manufacturing our measures of workplace innovation can account for over the period of 19931995. We present these calculations in Table 4 along with the figures reported by the BLS to "benchmark" our findings with their numbers. As seen in this table, the sample of EQW manufacturing establishments experienced very similar output growth over the period 1993-1996 as reported by the BLS for the country as a whole. ${ }^{16}$ The BLS reports that output growth in manufacturing grew at a compound average annual growth rate of 4.4 percent between 19931996. We find a slightly higher rate of 4.7 percent using the EQW cross sections over the same period. The BLS reports that combined inputs (capital, labor and materials) grew 2.5 percent over this period and using the estimated coefficient from Table 2, equation 3 as shares we find inputs grew 3.2 percent in the EQW survey. As a result, multifactor productivity grew 1.8

workplace practices. Time spent in meetings associated with self-managed teams or problem solving could reduce productivity in the short run but have a positive impact on productivity in the longer run.

${ }^{16}$ Bureau of Labor Statistics, Multifactor Productivity Trends in Manufacturing, 2000, released August 29, 2002 
percent in the BLS reported figures and 1.6 percent using EQW data. The advantage of the EQW surveys, however, is that now we can use our estimated coefficients and calculate the impact of workplace innovation on multifactor productivity. We find that they contributed 1.4 percent per year. In other words, workplace practices and re-engineering efforts accounted for approximately 30 percent of output growth in manufacturing over the period 1993-1996, or 89 percent of multifactor productivity. The number of 1.4 percent may sound high and we believe that this number should be treated as a rough upper bound since some of our workplace practices such as re-engineering reflect both technological as well as organizational changes.

Nevertheless, this accounting exercise suggests that understanding workplace innovation may go some way in explaining recent trends in multifactor productivity in the United States.

\section{Conclusions and Implications}

During the period 1993-1996 we find that U.S. manufacturing employers have been actively engaged in workplace re-organization and that these changes in workplace practices, along with increasing diffusion of computers, may well have played a significant role in the recent rise in manufacturing productivity. Workplace innovation, especially when it has occurred in unionized establishments, is positively associated with labor productivity in the United States. One explanation for this strong effect in unionized establishments is that workers may be more willing to participate in employee involvement programs if they feel the union will protect their employment security.

While our work, along with previous intra-industry studies, suggests a strong and positive relationship between workplace practices and productivity, the evidence of the effect of these 
practices on worker welfare is mixed. Aghion, Caroli and Garcia-Penalosa (1999) show that the impact of organizational change on wage inequality is theoretically ambiguous, for an economy as a whole and for specific employers. Therefore, the impact of workplace innovation on inequality becomes an empirical question. In Black, Lynch and Krivelyova (2003) we find that in U.S. manufacturing workplace innovation does seems to be associated with higher wage inequality within employers. Caroli and Van Reenen (2001) using data on British and French firms present evidence that suggests that workplace innovation may be skilled biased while we find a more mixed picture for US manufacturing that varies by union status of the establishment.

More generally, Gordon (2003) argues that part of the reason we see divergence in productivity growth between Europe and the US is due to much larger variation across countries in Europe in information technology usage. Our work suggests that while this may be part of the explanation for the recent divergence in productivity it may also be useful to examine differences in work organization practices across Europe to understand productivity differences. For example, Nickell and Van Reenen (2000), argue that the gap in relative productivity performance between Britain and the United States reflects not only a weakness of investment in high tech areas but also an inability by British employers to absorb best-practice techniques and methods in wide swathes of the market sector. They conclude that part of this is due to low levels of product market competition and general lack of exposure to best-practices methods and technology.

Nickell and Van Reenen (2000) and Metcalf (2002) also point out that the traditional more adversarial relations between labor and management in Britain often worked against innovation and lowered productivity. However they argue that since the mid 1990s there has 
been some indication of a major shift in labor management relations in Britain towards establishing joint decision making and problem solving arrangements between labor and management. Our work on U.S. employers suggests that there may be significant productivity benefits associated with such arrangements in conjunction with investments in new information and communication technology. However, whether or not US and European firms will be able to sustain the benefits from workplace innovation such as employee participation in decision making over the long run remains an open question. 


\section{References}

Aghion, P., Caroli, E. and Garcia-Penalosa, C. (1999). 'Inequality and Economic Growth: The Perspectives of the New Growth Theory.' Journal of Economic Literature, vol. 37(4), pp. 1615-60.

Bailey, T. (1993). 'Organizational Innovation in the Apparel Industry.' Industrial Relations, vol. 32, pp. 30-48.

Bartelsman, E.J., Becker, R. and Gray W. (2000). 'The NBER Manufacturing Productivity Database.' available at www.nber.org.

Batt, R. (1995). Performance and Welfare Effects of Work Restructuring: Evidence from Telecommunications Services. Cambridge, MA: Ph.D. dissertation, MIT Sloan School of Management.

Berg, P., Appelbaum, E., Bailey, T. and Kalleberg A. (1996). 'The Performance Effects of Modular Production in the Apparel Industry.' Industrial Relations, vol. 35, pp. 356-73.

Black, S.E. and Lynch, L.M. (1996). 'Human Capital Investments and Productivity.' American Economic Review, vol. 86(2), pp. 263-67.

Black, S.E. and Lynch, L.M. (2001). 'How to Compete: The Impact of Workplace Practices and Information Technology on Productivity.' Review of Economics and Statistics, August vol. 83(3), pp. 434-45.

Black, S.E. and Lynch, L.M. (2003). 'Measuring Organizational Capital in the New Economy.' In Measuring Capital in the New Economy, (ed. Corrado, C., Haltiwanger, J. and Sichel, D.). Chicgao, IL: University of Chicago Press, forthcoming.

Black, S.E., Lynch, L.M. and Krivelyova, A. (2003). 'How Workers Fare When Employers Innovate.' Industrial Relations, forthcoming.

Boning, B., Ichniowski, C. and Shaw, K. (2001). 'Opportunity Counts: Teams and the Effectiveness of Production Incentives.' National Bureau of Economic Research working

paper \#8306. 
Bresnahan, T., Brynjolfsson, E. and Hitt, L. (2002). 'Information Technology, Workplace Organization, and the Demand for Skilled Labor: Firm-Level Evidence.' Quarterly Journal of Economics, vol. 117(1), pp. 339-76.

Brynjolfsson, E. and Hitt, L. (2002). 'Computing Productivity: Firm Level Evidence.' Mimeo, The Wharton School, University of Pennsylvania.

Cappelli, P. and Neumark, D. (2001). 'Do 'High Performance' Work Practices Improve Establishment-Level Outcomes.' Industrial and Labor Relations Review, vol. 54(4), pp.737-75.

Caroli, E. and Van Reenen, J. (2001). 'Skilled Biased Organizational Change? Evidence from a Panel of British and French Establishments.' The Quarterly Journal of Economics, vol. 116(4), pp. 1449-92.

Cristini, A., Leoni, R., Gaj, A. and Labory, S. (2001). 'New workplace practices in Italy: Adoption and performance effects.' Mimeo, Università degli Studi di Bergamo, June.

Doms, M., Dunne, T. and Troske, K. (1997). 'Workers, Wages and Technology.' Quarterly Journal of Economics, vol. 112, (February), pp. 235-90.

Dunlop, J. and Weil, D. (1996). 'Diffusion and Performance of Modular Production in the U.S. Apparel Industry.' Industrial Relations, vol. 35, (July), pp.334-54.

Freeman, R. and Lazear, E. (1995). 'An Economic Analysis of Works Councils.' In Works Councils (ed. Rogers, J. and Streeck, W.), pp. 27-52. Chicago, IL: University of Chicago Press.

Gordon, R.J. (2003). 'High Tech Innovation and Productivity Growth: Does Supply Create Its Own Demand?.' National Bureau of Economic Research working paper no. 9437, January.

Griliches, Z. and Hausman, J.A. (1986). 'Errors in Variables in Panel Data.' Journal of Econometrics, vol. 31, pp. 93-118.

Griliches, Z. and Mairesse, J. (1995). 'Production Functions: The Search for Identification.' National Bureau of Economic Research working paper \# 5067.

Huselid, M.A. (1995). 'The Impact of Human Resource Management Practices 
on Turnover, Productivity, and Corporate Financial Performance.' Academy of Management Journal, vol. 38(3), pp. 635-72.

Huselid, M.A. and Becker, B.E.. (1996). 'High Performance Work Systems and Firm Performance: Cross-Sectional Versus Panel Results.' Industrial Relations ${ }_{2}$ vol. 35, pp. 400-22.

Ichniowski, C. (1990). 'Human Resource Management Systems and the Performance of U.S. Manufacturing Businesses.' National Bureau of Economic Research working paper \# 3449.

Ichniowski, C., Shaw, K. and Prennushi, G. (1997). 'The Effects of Human Resource Management Practices on Productivity.' American Economic Review, vol. 87, (June), pp. 291-313.

Jorgenson, D.W. and Stiroh, K.J. (2000). "Raising the Speed Limit: U.S. Economic Growth in the Information Age." Brookings Papers on Economic Activity, vol. 1, pp. 125-211.

Kandel, E. and Lazear, E. (1992). 'Peer Pressure and Partnerships.' Journal of Political Economy, vol. 100, pp. 801-17.

Kato, T. and Morishima, M. (2002). 'The Productivity Effects of Participatory Employment Practices: Evidence from New Japanese Panel Data,' Industrial Relations, vol. 4(4), pp. 487-520.

Kelley, M. (1994). 'Information Technology and Productivity: The Elusive Connection.' Management Science, vol. 40, pp. 1406-25.

Kelley, M. (1996). 'Participative Bureaucracy and Productivity in the Machined Products Sector.' Industrial Relations, vol. 35, pp. 374-99.

Krafcik, J. (1988). 'Triumph of the Lean Production System.' Sloan Management Review, vol. 30, pp. 41-52.

Krueger, A. (1993). 'How Computers Have Changed the Wage Structure: Evidence from Micro Data, 1984-1989.' Quarterly Journal of Economics, vol. 108, (February), pp.33-61.

Levinsohn, J. and Petrin, A. (2000). 'Estimating Production Functions Using Inputs to Control for Unobservables.' National Bureau of Economic Reserach working paper 
\#7819, August.

Malcomson, J. (1983). 'Trade Unions and Economic Efficiency.' ECONOMIC JOURNAL, vol. 93 , pp. 50-65.

Melitz, M.J. (2000). 'Estimating Firm-Level Productivity in Differentiated Product Industries.' Mimeo, Department of Economics, Harvard University, December.

Metcalf, D. (2002). 'Unions and Productivity, Financial Performance and Investment: International Evidence.' Centre for Economic Performance, London School of Economics, June.

Milgrom, P. and Roberts, J. (1995). 'Complementarities and Fit: Strategy, structure and organizational change in manufacturing.' Journal of Accounting and Economics, vol. 19, pp. 179-08.

Nickell, S.J. and Van Reenen, J. (2000). 'Technological Innovation and Economic Performance in the United Kingdom.' Centre for Economic Performance, London School of Economics working paper no. 51, December.

Oliner, S.D. and Sichel, D.E. (2000). 'The Resurgence of Growth in the Late 1990s: Is Information Technology the Story?' Journal of Economic Perspectives, vol. 14(4), pp. $3-22$.

Oliner, S.D. and Sichel, D.E. (2002). 'Information Technology and Productivity: Where are we going now?' Board of Governor of the Federal Reserve Bank Finance and Economics Discussion Series paper number 2002-29, June.

Scarpetta, S., Bassanini, A., Pilat, D., and Schreyer, P. (2000). 'Economic Growth in the OECD Area: Recent Trends at the Aggregate and Sectoral Level.' OECD economics department working paper no. 248, June.

Womack, J., Jones, D. and Roos, D. (1991). The Machine that Changed the World. New York, NY: Rawson/Macmillan. 
Fig. 1: Trends in Multifactor Productivity for U.S. Manufacturing (Average Annual Rates in \%)

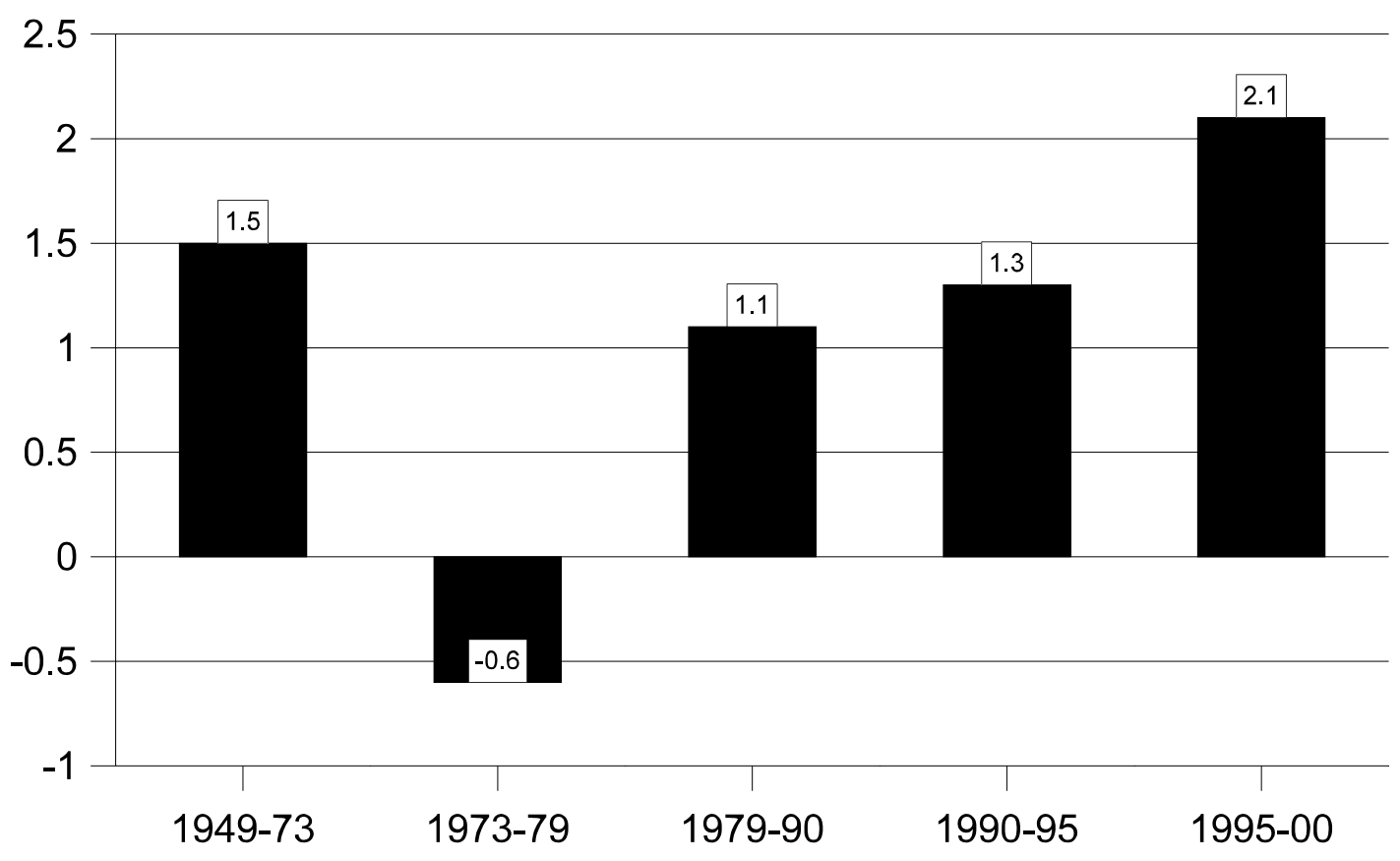

Source: U.S. Bureau of Labor Statistics: Multifactor Productivity Trends in Manufacturing, 2000, news release date August 29, 2002. http://www.bls.gov/news.release/prod5.nr0.htm 


\section{Fig. 2: Incidence of Workplace Practices}

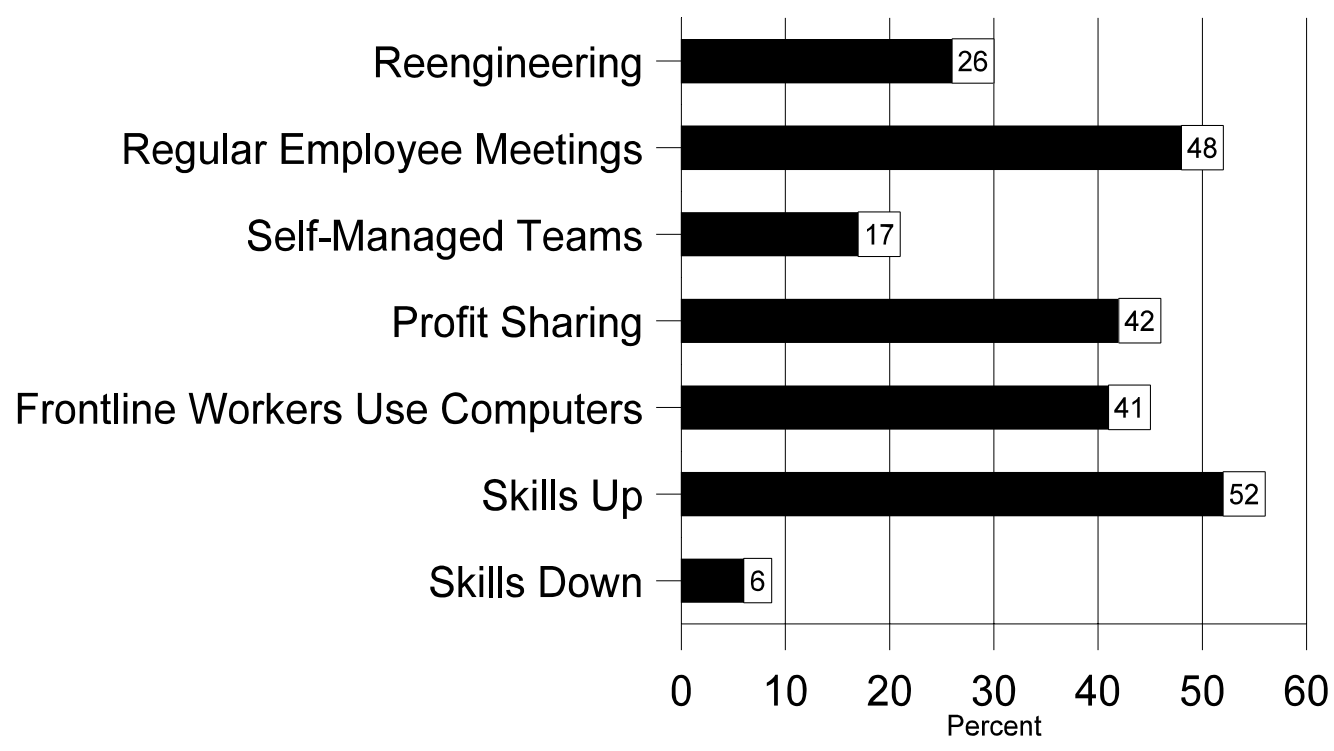

Source: EQW $2^{\text {nd }}$ Round Survey. Weighted data on U.S. establishment practices in 1996. Definitions: Reengineering - any re-engineering efforts over the past three years; regular employee meetings - \% of establishments reporting $75 \%$ or more of workers meeting regularly to discuss workplace issues; self managed teams - $\%$ of employers reporting $25 \%$ or more of their employees in self-managed teams; and frontline workers using computers - $\%$ of businesses reporting that $75 \%$ of more of their frontline workers use computers.

Table 1: Changes in Organizational Structure (1993-1996) 


\begin{tabular}{lccc}
\hline & $\begin{array}{c}\text { \% Increased } \\
\text { (Moved into } \\
\text { Group) }\end{array}$ & $\begin{array}{c}\text { \% Decreased } \\
\text { (Moved out of } \\
\text { Group) }\end{array}$ & $\begin{array}{c}\text { \% Stayed the } \\
\text { Same }\end{array}$ \\
\hline $\begin{array}{l}>25 \% \text { of Workers in Self- } \\
\text { Managed Teams }\end{array}$ & 13 & 7 & 80 \\
\hline Profit sharing & 4 & 26 & 70 \\
\hline$>75 \%$ of workers using & 11 & 11 & 78 \\
$\begin{array}{l}\text { Computers } \\
\text { P75\% of workers meeting }\end{array}$ & 22 & 12 & 66 \\
regularly in groups & & & \\
\hline
\end{tabular}

Number of observations $=284$

Source: EQW-NES data. 
Table 2: Determinants of Labor Productivity: 1996 Cross Section

\begin{tabular}{|c|c|c|c|c|}
\hline Variable & $\begin{array}{l}\text { Mean } \\
\text { (s.d.) }\end{array}$ & $\begin{array}{l}\text { Column } 1 \\
\text { Coefficient } \\
\text { (t-statistic) } \\
\end{array}$ & $\begin{array}{l}\text { Column } 2 \\
\text { Coefficient } \\
\text { (t-statistic) } \\
\end{array}$ & $\begin{array}{l}\text { Column } 3 \\
\text { Coefficient } \\
\text { (t-statistic) }\end{array}$ \\
\hline Ln (Capital/Workers) & & $\begin{array}{l}0.133^{* *} \\
(10.84)\end{array}$ & $\begin{array}{l}0.138^{* *} \\
(11.108)\end{array}$ & $\begin{array}{l}0.137 * * \\
(11.092)\end{array}$ \\
\hline Ln (Materials/Workers) & & $\begin{array}{c}0.476^{* *} \\
(34.2)\end{array}$ & $\begin{array}{l}0.483 * * \\
(34.614)\end{array}$ & $\begin{array}{l}0.483 * * \\
(34.573)\end{array}$ \\
\hline $\begin{array}{l}\text { Ln } \\
\text { (Nonproduction/Production) }\end{array}$ & & & $\begin{array}{l}0.286^{* *} \\
(17.33)\end{array}$ & $\begin{array}{l}0.286^{* *} \\
(17.321)\end{array}$ \\
\hline \multicolumn{5}{|c|}{ Technology } \\
\hline Share of Equip $<1 \mathrm{yr}$. & $\begin{array}{c}0.116 \\
(0.142)\end{array}$ & $\begin{array}{c}0.115 \\
(0.962)\end{array}$ & $\begin{array}{c}0.094 \\
(0.775)\end{array}$ & $\begin{array}{l}0.095 \\
(0.779)\end{array}$ \\
\hline Share of Equip 1-4 yr. old & $\begin{array}{l}0.294 \\
(0.222)\end{array}$ & $\begin{array}{c}0.199 * * \\
(2.496)\end{array}$ & $\begin{array}{c}0.231 * * \\
(2.87)\end{array}$ & $\begin{array}{l}0.221 * * \\
(2.737)\end{array}$ \\
\hline $\begin{array}{l}\text { Proportion Non-Managers } \\
\text { using Computers }\end{array}$ & $\begin{array}{c}0.414 \\
(0.364)\end{array}$ & $\begin{array}{c}0.288 * * \\
(5.438)\end{array}$ & $\begin{array}{c}0.267 * * \\
(5.021)\end{array}$ & $\begin{array}{c}0.277 * * \\
(5.165)\end{array}$ \\
\hline \multicolumn{5}{|c|}{ Worker Characteristics } \\
\hline Ln (Average Education) & $\begin{array}{c}2.54 \\
(0.082)\end{array}$ & $\begin{array}{c}0.693 * * \\
(2.90)\end{array}$ & & \\
\hline $\begin{array}{l}\text { Ln (Avg Ed Nonproduction } \\
\text { Workers) }\end{array}$ & $\begin{array}{l}2.62 \\
(0.077)\end{array}$ & & $\begin{array}{l}0.117 \\
(0.497)\end{array}$ & $\begin{array}{l}0.150 \\
(0.636)\end{array}$ \\
\hline $\begin{array}{l}\text { Ln (Avg Ed Production } \\
\text { Workers) }\end{array}$ & $\begin{array}{l}2.47 \\
(0.113)\end{array}$ & & $\begin{array}{l}-0.33 \\
(-1.988)\end{array}$ & $\begin{array}{c}-0.349 * * \\
(-2.101)\end{array}$ \\
\hline $\begin{array}{l}\text { Turnover (proportion } \\
\text { employees }<1 \text { year) }\end{array}$ & $\begin{array}{c}0.149 \\
(0.157)\end{array}$ & $\begin{array}{r}-0.428 * * \\
(-3.731)\end{array}$ & $\begin{array}{l}-0.392 * * \\
(-3.377)\end{array}$ & $\begin{array}{c}-0.376 * * \\
(-3.239)\end{array}$ \\
\hline $\begin{array}{l}\text { Proportion employees } \\
\text { Women }\end{array}$ & $\begin{array}{c}0.375 \\
(0.247)\end{array}$ & $\begin{array}{l}-0.066 \\
(-0.846)\end{array}$ & $\begin{array}{l}-0.046 \\
(-0.589)\end{array}$ & $\begin{array}{c}-0.054 \\
(-0.683)\end{array}$ \\
\hline $\begin{array}{l}\text { Proportion employees } \\
\text { Minority }\end{array}$ & $\begin{array}{c}0.272 \\
(0.260)\end{array}$ & $\begin{array}{l}0.070 \\
(1.047)\end{array}$ & $\begin{array}{l}0.078 \\
(1.148)\end{array}$ & $\begin{array}{l}0.085 \\
(1.262)\end{array}$ \\
\hline \multicolumn{5}{|c|}{ Use of High Performance Work Systems } \\
\hline Re-engineering & $\begin{array}{l}0.376 \\
(0.484)\end{array}$ & $\begin{array}{l}0.061^{*} \\
(1.676)\end{array}$ & $\begin{array}{l}0.062^{*} \\
(1.679)\end{array}$ & $\begin{array}{l}0.047 \\
(0.764)\end{array}$ \\
\hline Benchmarking & $\begin{array}{l}0.332 \\
(0.471)\end{array}$ & $\begin{array}{l}0.001 \\
(0.024)\end{array}$ & $\begin{array}{l}0.005 \\
(0.145)\end{array}$ & $\begin{array}{l}0.007 \\
(0.200)\end{array}$ \\
\hline $\begin{array}{l}\text { Number of Managerial } \\
\text { Levels }\end{array}$ & $\begin{array}{l}2.63 \\
(1.92)\end{array}$ & $\begin{array}{l}-0.003 \\
(-0.389)\end{array}$ & $\begin{array}{l}-0.009 \\
(-1.053)\end{array}$ & $\begin{array}{l}-0.010 \\
(-1.178)\end{array}$ \\
\hline $\begin{array}{l}\text { Proportion workers in self- } \\
\text { managed teams }\end{array}$ & $\begin{array}{c}0.151 \\
(0.289)\end{array}$ & $\begin{array}{c}0.024 \\
(0.396)\end{array}$ & $\begin{array}{l}0.070 \\
(1.142)\end{array}$ & $\begin{array}{l}0.089 \\
(1.262)\end{array}$ \\
\hline $\begin{array}{l}\text { Profit sharing or Stock } \\
\text { options }\end{array}$ & $\begin{array}{c}0.516 \\
(0.499)\end{array}$ & $\begin{array}{l}0.103 * * \\
(2.936)\end{array}$ & $\begin{array}{l}0.105^{* *} \\
(2.947)\end{array}$ & $\begin{array}{l}0.167 * * \\
(3.991)\end{array}$ \\
\hline
\end{tabular}


Employee Voice

\begin{tabular}{|c|c|c|c|c|}
\hline Unionized & $\begin{array}{c}0.304 \\
(0.460)\end{array}$ & $\begin{array}{l}0.072 * \\
(1.816)\end{array}$ & $\begin{array}{l}0.092 * * \\
(2.283)\end{array}$ & $\begin{array}{l}0.168 * * \\
(2.338)\end{array}$ \\
\hline $\begin{array}{l}\text { Proportion Workers meeting } \\
\text { regularly in Groups }\end{array}$ & $\begin{array}{c}0.524 \\
(0.436)\end{array}$ & $\begin{array}{l}-0.061 \\
(-1.525)\end{array}$ & $\begin{array}{l}-0.007 * \\
(-1.655)\end{array}$ & $\begin{array}{l}-0.054 \\
(-1.008)\end{array}$ \\
\hline \multicolumn{5}{|c|}{ Recruitment Strategies } \\
\hline $\begin{array}{l}\text { Grades a top priority in } \\
\text { recruitment }\end{array}$ & $\begin{array}{c}0.163 \\
(0.369)\end{array}$ & $\begin{array}{l}-0.019 \\
(-0.412)\end{array}$ & $\begin{array}{l}-0.020 \\
(-0.425)\end{array}$ & $\begin{array}{l}-0.012 \\
(-0.258)\end{array}$ \\
\hline $\begin{array}{l}\text { Communication a top priority } \\
\text { in recruitment }\end{array}$ & $\begin{array}{l}0.560 \\
(0.497)\end{array}$ & $\begin{array}{c}0.008 \\
(0.213)\end{array}$ & $\begin{array}{l}-0.010 \\
(-0.287)\end{array}$ & $\begin{array}{l}-0.008 \\
(-0.208)\end{array}$ \\
\hline \multicolumn{5}{|c|}{ Interaction Terms } \\
\hline Union*profit sharing & $\begin{array}{c}0.169 \\
(0.375)\end{array}$ & & & $\begin{array}{l}-0.218 * * \\
(-2.904)\end{array}$ \\
\hline Union*re-engineering & $\begin{array}{l}0.129 \\
(0.336)\end{array}$ & & & $\begin{array}{l}0.121 * \\
(1.60)\end{array}$ \\
\hline Union $* \%$ meet & $\begin{array}{c}0.147 \\
(0.324)\end{array}$ & & & $\begin{array}{l}0.011 \\
(0.124)\end{array}$ \\
\hline$\%$ meet*re-engineering & $\begin{array}{c}0.206 \\
(0.371)\end{array}$ & & & $\begin{array}{l}-0.041 \\
(-0.506)\end{array}$ \\
\hline $\begin{array}{l}\text { Union*\% in self-managed } \\
\text { teams }\end{array}$ & $\begin{array}{c}0.041 \\
(0.158)\end{array}$ & & & $\begin{array}{l}-0.100 \\
(-0.736)\end{array}$ \\
\hline $\mathrm{N}=$ & 1493 & 1493 & 1493 & 1493 \\
\hline Adjusted $\mathrm{R}^{2}=$ & & 0.645 & 0.822 & 0.823 \\
\hline
\end{tabular}

Estimated equations are augmented Cobb-Douglas production functions and also include a constant term, 2-digit SIC industry controls, and a dummy if the establishment is part of a multi-establishment firm. Columns 2 and 3 divide workers into production and non-production workers. All equations impose constant returns to scale. Standard errors were adjusted for heteroskedasticity.

$* *$ denotes significance at the $5 \%$ level.

* denotes significance at the $10 \%$ level. 
Table 3: Determinants of Labor Productivity: Fixed Effects Model (1996-1993)

T-statistics in parenthesis

\begin{tabular}{|c|c|c|c|c|}
\hline Variable & $\begin{array}{l}\text { Mean } \\
\text { (s.d.) }\end{array}$ & $\begin{array}{l}\text { Column } 1 \\
\text { Coefficient } \\
\text { (t-statistic) }\end{array}$ & $\begin{array}{l}\text { Column } 2 \\
\text { Coefficient } \\
\text { (t-statistic) }\end{array}$ & $\begin{array}{l}\text { Column } 3 \\
\text { Coefficient } \\
\text { (t-statistic) } \\
\end{array}$ \\
\hline Ln (Capital/Workers) & & $\begin{array}{l}0.176 * * \\
(2.099)\end{array}$ & $\begin{array}{l}0.185 * * \\
(2.391)\end{array}$ & $\begin{array}{l}0.194 * * \\
(2.544)\end{array}$ \\
\hline Ln (Materials/Workers) & & $\begin{array}{l}0.259 * * \\
(3.315)\end{array}$ & $\begin{array}{l}0.277 * * \\
(3.604)\end{array}$ & $\begin{array}{l}0.274 * * \\
(3.675)\end{array}$ \\
\hline $\begin{array}{l}\text { Ln } \\
\text { (Nonproduction/Production) }\end{array}$ & & & $\begin{array}{l}0.301 * * \\
(4.665)\end{array}$ & $\begin{array}{l}0.300 * * \\
(4.743)\end{array}$ \\
\hline \multicolumn{5}{|c|}{ Technology } \\
\hline $\begin{array}{l}\text { Proportion Non-Managers } \\
\text { using Computers }\end{array}$ & $\begin{array}{c}0.351 \\
(0.317)\end{array}$ & $\begin{array}{l}0.296 * * \\
(2.043)\end{array}$ & $\begin{array}{l}0.345^{* *} \\
(2.442)\end{array}$ & $\begin{array}{l}0.363 * * \\
(2.564)\end{array}$ \\
\hline \multicolumn{5}{|c|}{ Worker Characteristics } \\
\hline Ln (Average Education) & $\begin{array}{c}2.52 \\
(0.07)\end{array}$ & $\begin{array}{c}-0.70 \\
(-1.071)\end{array}$ & & \\
\hline $\begin{array}{l}\text { Ln (Avg Ed Nonproduction } \\
\text { Workers) }\end{array}$ & $\begin{array}{c}2.63 \\
(0.069)\end{array}$ & & $\begin{array}{c}-0.352 \\
(-0.525)\end{array}$ & $\begin{array}{l}-0.457 \\
(-0.674)\end{array}$ \\
\hline $\begin{array}{l}\text { Ln (Avg Ed Production } \\
\text { Workers) }\end{array}$ & $\begin{array}{c}2.47 \\
(0.070)\end{array}$ & & $\begin{array}{l}-0.909 * \\
(-1.802)\end{array}$ & $\begin{array}{l}-0.718 \\
(-1.342)\end{array}$ \\
\hline $\begin{array}{l}\text { Turnover (proportion } \\
\text { employees }<1 \text { year) }\end{array}$ & $\begin{array}{c}0.109 \\
(0.118)\end{array}$ & $\begin{array}{l}-0.932 \\
(-1.364)\end{array}$ & $\begin{array}{c}-1.057 * \\
(-1.65)\end{array}$ & $\begin{array}{l}-1.085^{*} \\
(-1.716)\end{array}$ \\
\hline $\begin{array}{l}\text { Proportion employees } \\
\text { Women }\end{array}$ & $\begin{array}{c}0.349 \\
(0.214)\end{array}$ & $\begin{array}{c}0.704 \\
(1.198)\end{array}$ & $\begin{array}{c}0.722 \\
(1.234)\end{array}$ & $\begin{array}{c}0.813 \\
(1.381)\end{array}$ \\
\hline $\begin{array}{l}\text { Proportion employees } \\
\text { Minority }\end{array}$ & $\begin{array}{c}0.272 \\
(0.252)\end{array}$ & $\begin{array}{l}-0.255 \\
(-1.069)\end{array}$ & $\begin{array}{c}-0.168 \\
(-0.670)\end{array}$ & $\begin{array}{l}-0.117 \\
(-0.453)\end{array}$ \\
\hline \multicolumn{5}{|c|}{ Use of High Performance Work Systems } \\
\hline Re-engineering & $\begin{array}{l}0.426 \\
(0.495)\end{array}$ & $\begin{array}{l}0.205 * * \\
(2.667)\end{array}$ & $\begin{array}{l}0.201 * * \\
(2.619)\end{array}$ & $\begin{array}{l}0.312 * \\
(1.72)\end{array}$ \\
\hline Benchmarking & $\begin{array}{l}0.408 \\
(0.492)\end{array}$ & $\begin{array}{l}-0.045 \\
(-0.491)\end{array}$ & $\begin{array}{c}-0.034 \\
(-0.370)\end{array}$ & $\begin{array}{c}-0.04 \\
(-0.421)\end{array}$ \\
\hline $\begin{array}{l}\text { Number of Managerial } \\
\text { Levels }\end{array}$ & $\begin{array}{c}2.71 \\
(2.12)\end{array}$ & $\begin{array}{c}0.003 \\
(0.200)\end{array}$ & $\begin{array}{c}0.001 \\
(0.072)\end{array}$ & $\begin{array}{c}-0.003 \\
(-0.176)\end{array}$ \\
\hline $\begin{array}{l}\text { Proportion workers in self- } \\
\text { managed teams }\end{array}$ & $\begin{array}{c}0.172 \\
(0.300)\end{array}$ & $\begin{array}{c}-0.545^{* *} \\
(-2.278)\end{array}$ & $\begin{array}{c}-0.536^{* *} \\
(-2.242)\end{array}$ & $\begin{array}{c}-0.535^{* *} \\
(-1.968)\end{array}$ \\
\hline Profit sharing & $\begin{array}{c}0.63 \\
(0.483)\end{array}$ & $\begin{array}{c}0.041 \\
(0.673)\end{array}$ & $\begin{array}{c}0.042 \\
(0.647)\end{array}$ & $\begin{array}{c}0.017 \\
(0.221)\end{array}$ \\
\hline
\end{tabular}




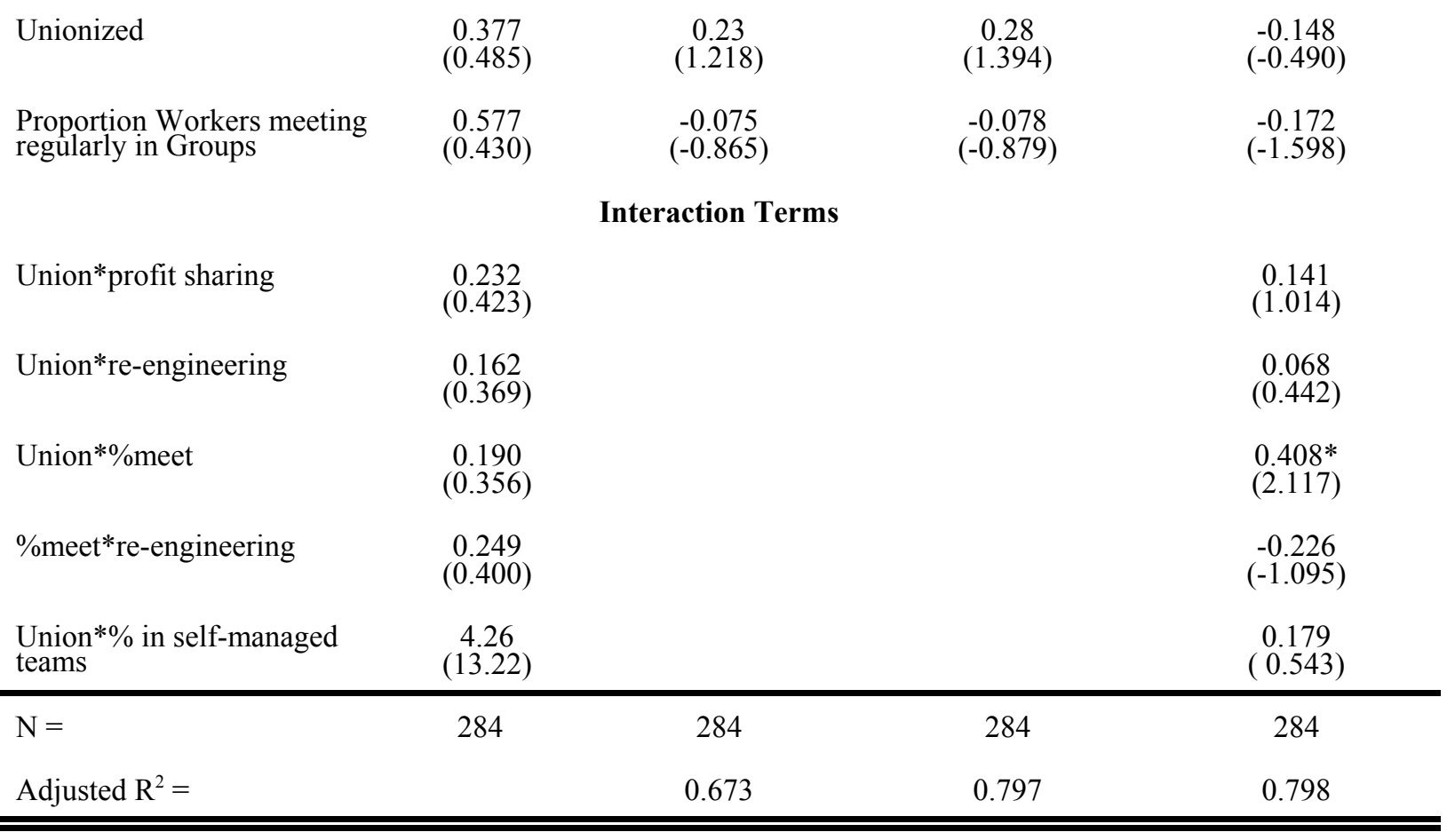

Estimated equations are augmented Cobb-Douglas production functions. Columns 2 and 3 divide workers into production and non-production workers. All equations impose constant returns to scale.. Estimated equations also include a constant term. Standard errors were adjusted for heteroskedasticity.

$* *$ denotes significance at the $5 \%$ level.

* denotes significance at the $10 \%$ level. 


\section{Table 4: $\quad$ Compound Average Annual Rates of Growth in Output and the Contribution of Factor Inputs and Multifactor Productivity for Manufacturing (percent per year)}

\begin{tabular}{|c|c|c|c|c|c|c|}
\hline & \multicolumn{5}{|c|}{ BLS } & EQW-NES \\
\hline & $\begin{array}{l}1949- \\
2000\end{array}$ & $\begin{array}{l}1979- \\
1990\end{array}$ & $\begin{array}{l}1990- \\
1995\end{array}$ & $\begin{array}{l}1995- \\
2000\end{array}$ & $\begin{array}{l}1993- \\
1996\end{array}$ & $\begin{array}{l}1993- \\
1996\end{array}$ \\
\hline Output & 3.3 & 2.0 & 3.1 & 4.1 & 4.4 & 4.7 \\
\hline $\begin{array}{l}\text { Combined Inputs }{ }^{1} \\
\text { (includes capital, } \\
\text { labor, materials) }\end{array}$ & 2.1 & 0.9 & 1.8 & 2.0 & 2.5 & 3.2 \\
\hline Multifactor Productivity & 1.2 & 1.1 & 1.3 & 2.1 & 1.8 & 1.6 \\
\hline $\begin{array}{l}\text { Contribution of } \\
\text { Workplace Practices }\end{array}$ & - & & - & - & - & 1.4 \\
\hline Remaining Residual & - & & - & - & - & 0.2 \\
\hline
\end{tabular}

Source: Bureau of Labor Statistics, Multifactor Productivity Trends in Manufacturing, 2000, released August 29, 2002 and authors' own calculations from the EQW-NES first and second round cross sections with a $1 \%$ trim.

1. The growth rate of each input is weighted by its share of nominal costs in the BLS figures and by the estimated coefficient in Table 3 equation 3 for the EQW-NES figures.

2. This calculation is based on the change in workplace practices and worker characteristics reported in the 1993 and 1996 EQW-NES cross sections weighted by the coefficients on workplace practices and worker characteristics presented in Table 3, equation 3. 


\section{DATA APPENDIX}

The price deflators for shipments were constructed from 5-digit product deflators from BEA using the Bartelsman, Becker and Gray (2000) data set. These are largely created from the Bureau of Labor Statistics' (BLS) industry-based producer prices which are extrapolated backwards using the old BLS product prices. These data contain the BEA's computer deflator which is adjusted for quality using hedonic techniques.

The capital deflator is created by first generating a 3-digit industry real net capital stock value. The 3-digit data are converted to the 4-digit level by assuming that the industry-asset type flows are the same for all 4-digit industries within a 3-digit industry. With this information, 4digit investment deflators are created for equipment and structures separately. Again, this deflator also incorporates the hedonic adjustment for quality changes in computers.

The materials deflator is created by averaging together price deflators for 529 inputs (369 manufacturing industries and 160 non-manufacturing industries), using as weights the relative size of each industry's purchases of that input in the Input-Output Tables. The inflation in materials prices is calculated as a Tornquist index (weighting each product's inflation rate by the average of the previous and current-year's shares in total materials used).

The energy price deflator is based on each industry's expenditures on six types of energy (electricity, residual fuel oil, distillates, coal, coke and natural gas). These six types of energy represent 94.6 percent of all energy expenditures by the manufacturing sector in 1976 . They are a majority of the energy costs for all but one industry, and over 90 percent of energy costs for 300 of the industries. 